Pobrane z czasopisma Annales H - Oeconomia http://oeconomia.annales.umcs.pl Data: 26/04/2023 16:58:36

DOI:10.17951/h.2017.51.5.339

\begin{tabular}{lcc}
\hline \multicolumn{3}{c}{ A N N A L E S } \\
UNIVERSITATIS & MARIAE CURIE-SKŁODOWSKA \\
LUBLIN - POLONIA & \\
VOL. LI, 5 & SECTIOH H \\
\hline
\end{tabular}

Poznań University of Economics and Business. Faculty of Informatics and Electronic Economy

ALEKSANDRA WÓJCICKA

aleksandra.wojcicka@ue.poznan.pl

\title{
Neural Networks vs Discriminant Analysis in the Assessment of Default
}

Porównanie wykorzystania sieci neuronowych i analizy dyskryminacyjnej w ocenie niewypłacalności

Keywords: credit risk; default; neural networks; discriminant analysis; financial indices

Słowa kluczowe: ryzyko kredytowe; sieci neuronowe; analiza dyskryminacyjna; analiza finansowa

JEL Code: G33; C38; C49

\section{Introduction}

Identifying potential healthy and unsound customers is an extremely important task. The reduction of loans granted to companies of questionable creditability can significantly influence and improve banks' performance. The most important element in categorizing debtors is a prior identification of factors that affect the condition of companies as it directly influences the credibility and solvency of the entity and both of these factors result in low or high probability of default.

Due to increased bankruptcies noted among companies, banks pay more attention to credit risk management and evaluation of potential debtor's default. Unfortunately, analysts often need to choose between accuracy, efficiency and simplicity of chosen methods. However, the implementation of various tools should provide banks with an opportunity to quickly identify and preselect companies that are in financial distress. This pre-selection should be followed by a more thorough analysis. It must be stressed that a correct pre-selection is both, cost- and time-effective. 
Ideally, a pre-selection tool should be uniform for all businesses. However, previous research shows that this goal cannot always be achieved [Wójcicka, 2016a, 2016b, 2016c].

Amongst the most commonly used methods assisting the decision-making process we can enumerate Discriminant Analysis (DA), scoring methods, and Neural Networks (NN). However, each method and models has its own advantages and disadvantages. In case of neural networks that disadvantage is often referred to the way NN work - as "black boxes". It means that part of the computing is hidden in the layers and is inaccessible to the researcher. However, discriminant analysis models (or Z-score models) also have (or might have) a zone of indecision which also might be considered a "black box".

The paper investigates the use of NN of different architectures and various DA models in the process of establishing the possible default of the debtor. The results of those different methods and models are juxtaposed and their performance compared in a number of sectors.

The study can be classified in applied studies group and the research strategy is descriptive. The main objective of the study is to deliver an answer of which method is more efficient in credit risk management.

\section{Literature review}

The literature on discriminant analysis and neural networks is very broad. DA models are a specific kind of financial analysis in which a weight is given to each factor and which enables to classify the companies. Multi-factor DA has been present since the 1960s when Altman presented his first model which became a benchmark for all that followed [Altman, 1968]. Since that time DA has been improved and tested by many other authors. Beside the DA models used in this research (see 3.1) there are models of Appenzeller and Szarzec [2004], Stępień and Strąk [2004], Wędzki [2005], Hołda [2001], etc. The choice of DA models (5) was not random and was dictated by their efficiency of classification in previous research.

Neural networks in the scope of credit risk are broadly analysed. Atiya [2001] presents an empirical approach, basing on the relationship of default and the characteristics of a firm learnt from the data. The conclusions indicate the superiority of neural networks over other techniques and the need for improvements in training methods, architecture selection, or input. Baesens et al. [2003] investigated neural networks' contribution in helping the credit-risk managers in explaining why a particular applicant is classified as either bad or good. They conclude that neural network rule extraction and decision trees are effective and powerful management tools, allowing the construction of advanced and user-friendly decision-support systems for credit-risk evaluation.

Also in the work of Pacelli and Azzollini [2011] it is stated that neural networks are particularly suited to analyse and interpret complex and often obscure phenomena and processes. 
Still, other research proves that despite the weaknesses, neural networks show good performance when data are noisy or incorrect [see: Angelini, di Tollo, Roli, 2008; Tollo, 2006]. In these studies, the most common NN were analysed. Other structures of neural networks, as well as their comparison with other techniques (Decision Trees, Discriminant Analysis, Regression Function, etc.), can be found in the works of e.g. Khemakhem and Boujelbènea [2015], Karaa and Krichene [2012], Huang, Chen and Hsu [2004], Oreski, Oreski and Oreski [2012], Ogwueleka et al. [2015], Linder, Geier and Kölliker [2004] and many others.

\section{Data and main research frame}

The collected data was obtained from a bank operating on Polish market, the Commercial Court in Poznań and from Notoria Serwis. The data cover a period of 2009-2015. It refers to companies from three sectors (construction, industry, trade). These sectors cover a wide variety of companies. The sample contains financial statements of companies. Preliminary, data set was divided into three groups in a following manner:

- learning group ( $80 \%$ of data set),

- testing group ( $10 \%$ of data set),

- independent validation group (10\% of data set).

The study was conducted in two parallel ways. First, despite the chosen approach, equipotent sets of objects were determined (bad and good companies). Then, required ratios utilized in DA were calculated. That input was implemented in both approaches (DA and NN). Ratios used in a specific DA model were also utilized in case of each architecture of NN (Multi-Layer Perceptron, Radial Basis Function). The appropriate calculations were carried out. Next, the classification results of DA model and the best $\mathrm{NN}$, with identical input, were compared.

In the successive test, another approach was implemented. DA results for all the tested objects remained the same, however, for the same sample of entities (healthy and unsound) other set of ratios was used as an input. That input (sets containing 5-11 ratios) was selected basing on previous research [Wójcicka, 2016a, 2016b, 2016c] and varied depending on the sector of business.

\section{Findings}

Because two different methods are considered in the research, the preliminary findings will be presented separately in $3.1(\mathrm{DA})$ and $3.2(\mathrm{NN})$. Then the comparison will follow respectively in 3.3 and 3.4 (depending on the input). 


\subsection{Discriminant Analysis}

This study concerns only existing models (5) of various authors. Presented models were created basing on national data which is beneficial as every economy is of a specific character. To implement Discriminant Analysis (DA), two independent sets of samples are necessary. These include unsound and healthy companies. The sample must be balanced.

In the study, unsound companies were matched with healthy businesses similar in assets value and branch of economy (construction, industry and trade). Models used for comparison with neural networks are as follows: Gajdka and Stos [1996], Hadasik [1998], Wierzba [2000], "poznański”, Prusak [2005]. The choice of these models was dictated by the interest they still arouse among researchers as well as the prior own research.

Tab. 1. Formulas of Z-score models used in the analysis

\begin{tabular}{|c|c|c|}
\hline Model & Formula & Ratios \\
\hline $\begin{array}{l}\text { Gajdka and } \\
\text { Stos }\end{array}$ & $\begin{array}{l}Z_{\text {J.G.J.S. }}=0.7732059-0.0856425 X_{1} \\
+0.0007747 X_{2}+0.9220985 X_{3}+ \\
0.6535995 X_{4}-0.594687 X_{5}\end{array}$ & $\begin{array}{l}\mathrm{X}_{1}-(\text { sale net revenues/average annual value of assets }) \\
\mathrm{X}_{2}-\text { (average value of short-term liabilities/cost of sold } \\
\quad \text { production } * 360) \\
\mathrm{X}_{3}-\text { (net profit/average annual value of assets) } \\
\mathrm{X}_{4}-\text { (gross profit/net revenues on sales) } \\
\mathrm{X}_{5}-\text { (total liabilities/total assets) }\end{array}$ \\
\hline Hadasik & $\begin{array}{l}Z_{\text {D.H. }}=0.335969 X_{1}-0.71245 X_{2} \\
-2.476 X_{5}+1.46434 X_{7}+ \\
0.00246069 X_{9}-0.0138937 X_{12}+ \\
0.0243387 X_{17}+2.59323\end{array}$ & $\begin{array}{l}\mathrm{X}_{1}-\text { current assets/current liabilities } \\
\mathrm{X}_{2}-(\text { current assets }- \text { stocks }) / \text { current liabilities } \\
\mathrm{X}_{5}-\text { total liabilities/total assets } \\
\mathrm{X}_{7}-\text { working capital/total assets } \\
\mathrm{X}_{9}-(\text { average level of receivables/sales revenues }) * 365 \\
\left.\mathrm{X}_{12}-\text { (average level of stocks/sales revenues }\right) * 365 \\
\mathrm{X}_{17}-\text { net profit/average level of stocks }\end{array}$ \\
\hline Wierzba & $\begin{array}{l}\text { Zd.w. }=3.26 \mathrm{X}_{1}+2.16 \mathrm{X}_{2}+0.3 \mathrm{X}_{3} \\
+0.69 \mathrm{X}_{4}\end{array}$ & $\begin{array}{l}\mathrm{X}_{1}-(\text { operational activity profit }- \text { depreciation }) / \text { total assets } \\
\mathrm{X}_{2}-(\text { operational activity profit }- \text { depreciation }) / \text { sale of } \\
\quad \text { products } \\
\mathrm{X}_{3}-\text { current assets/total liabilities } \\
\mathrm{X}_{4}-\text { running capital/total assets }\end{array}$ \\
\hline $\begin{array}{l}\text { "Poznań- } \\
\text { ski" }\end{array}$ & $\begin{array}{l}Z_{\mathrm{Pn}}=3.526 \mathrm{X}_{1}+1.588 \mathrm{X}_{2}+4.288 \mathrm{X}_{3} \\
+6.719 \mathrm{X}_{4}-2.368\end{array}$ & $\begin{array}{l}\mathrm{X}_{1}-\text { net profit/total assets } \\
\left.\mathrm{X}_{2}-\text { (current assets }- \text { stocks }\right) / \text { short-term liabilities } \\
\mathrm{X}_{3}-\text { fixed capital/total assets } \\
\mathrm{X}_{4}-\text { sales profit/sales revenues }\end{array}$ \\
\hline Prusak & $\begin{array}{l}\mathrm{Z}_{\text {B.P. }}=1.438 \mathrm{X}_{1}+0.188 \mathrm{X}_{2}+ \\
5.023 \mathrm{X}_{3}-1.871\end{array}$ & $\begin{array}{l}\mathrm{X}_{1}-(\text { net profit }+ \text { depreciation }) / \text { total liabilities } \\
\mathrm{X}_{2}-\text { operational costs/current liabilities } \\
\mathrm{X}_{3}-\text { profit on sales/total assets }\end{array}$ \\
\hline
\end{tabular}

Source: [Gajdka, Stos, 1996; Hadasik, 1998; Hamrol, Czajka, Piechocki, 2004; Prusak, 2005].

Having the required financial ratios for each object, the next step was to calculate the values of Z-score for each model and entity. Then the accuracy of the model was determined. Type I error means that a specific model classifies a good customer as 
a bad customer and consequently, basing on such results of the model, a bank rejects the application of potential healthy client. Type II error means that model recognises a bad customer as a good customer and, therefore, a bank accepts the application and grants financing. Such situation is very likely to lead to customer's insolvency and consequently a bank might be forced to incur losses. Tab. 2 presents the results of type I and type II error of all tested models individually.

Tab. 2. Type I and II error for tested Z-score models

\begin{tabular}{|l|c|c|}
\hline \multicolumn{1}{|c|}{ Model } & Error - type I (\%) & Error - type II (\%) \\
\hline Gajdka and Stos & 9.33 & 21.75 \\
\hline Hadasik & 10.50 & 15.00 \\
\hline Wierzba & 11.67 & 16.67 \\
\hline "Poznański" & 8.75 & 14.33 \\
\hline Prusak & 9.33 & 13.67 \\
\hline
\end{tabular}

Source: own calculations.

As type II error is considered to be more significant for the banks it is justified to state that the best model is the one by Prusak (13.67\%). The next best was "poznański" model which also is characterised by the lowest level of type I error, which is considered to be less harmful for the banks. Due to rejection of good customers the bank can lose significant amount of money ("lost opportunities"). Therefore, too high level of that error also should be a concern.

Generally, all models achieved satisfactory levels, however, this satisfactory level might not always be sufficient in practice. Therefore, other alternatives (methods and models) are actively pursued.

\subsection{Neural networks}

The idea of neural networks as computing processors has its origin in the way a human brain computes and analyses obtained knowledge. Neural networks in the scientific literature can be defined as:

[...] a massively parallel distributed processor made up of simple processing units that has a natural propensity for storing experiential knowledge and making it available for use. It resembles the brain in two respects: i) Knowledge is acquired by the network from its environment through a learning process; ii) Interneuron connection strengths, known as synaptic weights, are used to store the acquired knowledge [Haykin, 2011].

A very important issue is the learning algorithm used in network design which influences the whole structure of NN. The different neural networks models used in the paper are Multi-Layer Perceptron (MLP) and Radial Basis Function neural network (RBF). 
The implemented tool is Statistica Neural Networks (SANN). Variables are divided into dependent and independent ones. Independent variables are the financial ratios of various groups:

- ratios used by analysed Z-score models,

- ratios selected in previous research [Wójcicka, 2016a, 2016b, 2016c].

The dependent variable was identified as a "good" or "bad" company. A "good" company was the one which was (or would be) granted financial resources and, consequently, the "bad" enterprise was the one that was denied funding. However, it must be stressed that the fact that a bank classified the company as a good debtor and was willing to grant the financial means is not unequivocal with final entering into the contract of a loan.

The research focuses on investigating and comparing the results of two different structures of neural networks - the most common Multi-Layer Perceptron and Radial Basis Function neural network.

Main similarities and differences between the two NN structures are presented in Tab. 3. The choice of these structures was dictated by their frequent use and popularity.

Tab. 3. Similarities and differences between MLP and RBF neural networks

\begin{tabular}{|l|l|l|}
\hline & \multicolumn{1}{|c|}{ MLP } & \multicolumn{1}{c|}{ RBF } \\
\hline Signal transmission & Feedforward & Feedforward \\
\hline $\begin{array}{l}\text { Process of building } \\
\text { the model }\end{array}$ & One stage & $\begin{array}{l}\text { Two different, independent stages - at the first stage by means of radial } \\
\text { basis functions the probability distribution is established; the network } \\
\text { learns the relations between input } \mathrm{x} \text { and output y at the second stage. } \\
\text { On the contrary to MLP the lag is only visible in RBF in the output } \\
\text { layer. }\end{array}$ \\
\hline Threshold & Yes & No \\
\hline Type of parameters & $\begin{array}{l}\text { Weights and } \\
\text { thresholds }\end{array}$ & $\begin{array}{l}\text { Location and width of basis function, } \\
\text { Weights binding basis functions with output }\end{array}$ \\
\hline Functioning time & Faster & Slower (bigger memory required) \\
\hline Learning time & Slower & Faster \\
\hline
\end{tabular}

Source: own elaboration based on: [Kowalski, 2011; Gaudart, Giusiano, Huiart, 2004; Nigrin, 1993; Statistica Help $(\mathrm{SANN})]$.

\subsection{Results for NN and DA - initial input of ratios from DA}

The first phase of analysis focused on the results of $\mathrm{NN}$ when the input consisted of the ratios selected by the discriminant analysis. This means that networks learnt on exactly the same sample of data as the other tested models (Z-score models). This experiment was to demonstrate and assess whether the initial input should vary when it comes to the used method or whether it is indifferent. The accuracy results of the best NN (MLP and RBF), with reference to individual DA models, are presented in Tab. 4. 
Pobrane z czasopisma Annales H - Oeconomia http://oeconomia.annales.umcs.pl Data: 26/04/2023 16:58:36

NEURAL NETWORKS VS DISCRIMINANT ANALYSIS IN THE ASSESSMENT OF DEFAULT

Tab. 4. Results of MLP and RBF neural networks quality in \% (input - ratios selected by DA)

\begin{tabular}{|l|c|c|}
\hline \multicolumn{1}{|c|}{ Models } & MLP & RBF \\
\hline Gajdka and Stos & 83.33 & 88.33 \\
\hline Hadasik & 80.00 & 86.67 \\
\hline Wierzba & 80.00 & 86.67 \\
\hline "Poznański" & 78.33 & 87.75 \\
\hline Prusak & 76.67 & 78.33 \\
\hline
\end{tabular}

Source: own calculations on the basis of Statistica Help (SANN).

The best results were achieved in case of a combination of RBF-"poznański" (87.75\%). It can be noticed that MLP generally, despite the chosen Z-score model, achieved lower level of accuracy in classification of objects. The average decrease of classification accuracy between MLP and RBF is more than $8 \%$.

However, it should be stressed that none of the neural networks, using on the initial input from the DA models, achieved the level of classification accuracy higher than $87.75 \%$ which might be acknowledged as not a sufficient result. It is also worth emphasising that the combinations which reached the lowest level are the ones in combination with model by Prusak. In this case the input consisted only of three financial ratios. Previous research on MLP and RBF indicated that the best results are of accuracy are reached in case of at least seven different ratios that act as the input. Current situation with both combinations (MLP-Prusak, RBF-Prusak) seems to prove that condition of input sufficiency.

\subsection{Results for NN and DA - various input of ratios}

In the second phase, another approach was implemented. The DA models still utilised the chosen set of input, defined individually by each model. However, neural networks used other set of financial ratios, depending on the sector of business represented by the objects. In terms of represented sector, there were three different groups: construction, industry, trade. The ratios used were identified in an iterative approach. The initial set of ratios contained 25 various financial ratios. In case of the examined sectors selected ratios are presented in Tab. 5 .

Tab. 5. Comparison of ratios used for the analysis of trade, construction, and industrial sectors

\begin{tabular}{|c|l|c|c|c|c|c|c|}
\hline \multirow{2}{*}{ No. Ratios } & \multicolumn{2}{|c|}{ Trade sector } & \multicolumn{2}{c|}{ Construction sector } & \multicolumn{2}{c|}{ Industrial sector } \\
\cline { 3 - 8 } & & MLP & RBF & MLP & RBF & MLP & RBF \\
\hline 1. & Current ratio & $\mathrm{x}$ & $\mathrm{x}$ & $\mathrm{x}$ & $\mathrm{x}$ & & \\
\hline 2. & Receivables ratio & & & $\mathrm{x}$ & $\mathrm{x}$ & $\mathrm{x}$ & $\mathrm{x}$ \\
\hline 3. & Operating activity profitability index & & & $\mathrm{x}$ & $\mathrm{x}$ & $\mathrm{x}$ & $\mathrm{x}$ \\
\hline 4. & Financial surplus rate & $\mathrm{x}$ & $\mathrm{x}$ & $\mathrm{x}$ & $\mathrm{x}$ & $\mathrm{x}$ & $\mathrm{x}$ \\
\hline 5. & Total debt ratio & $\mathrm{x}$ & $\mathrm{x}$ & $\mathrm{x}$ & $\mathrm{x}$ & $\mathrm{x}$ & $\mathrm{x}$ \\
\hline 6. & Costs level ratio & & & $\mathrm{x}$ & $\mathrm{x}$ & & \\
\hline 7. & Assets profitability index & & & $\mathrm{x}$ & $\mathrm{x}$ & $\mathrm{x}$ & $\mathrm{x}$ \\
\hline
\end{tabular}


Pobrane z czasopisma Annales H - Oeconomia http://oeconomia.annales.umcs.pl

Data: 26/04/2023 16:58:36

ALEKSANDRA WÓJCICKA

\begin{tabular}{|r|l|c|c|c|c|c|c|}
\hline \multirow{2}{*}{ No. Ratios } & \multicolumn{2}{|c|}{ Trade sector } & \multicolumn{2}{c|}{ Construction sector } & \multicolumn{2}{c|}{ Industrial sector } \\
\cline { 3 - 8 } & & $\mathrm{MLP}$ & $\mathrm{RBF}$ & $\mathrm{MLP}$ & $\mathrm{RBF}$ & $\mathrm{MLP}$ & $\mathrm{RBF}$ \\
\hline 8. & Financial leverage & $\mathrm{x}$ & $\mathrm{x}$ & $\mathrm{x}$ & $\mathrm{x}$ & & $\mathrm{x}$ \\
\hline 9. & Operating activity profitability index & & & & $\mathrm{x}$ & $\mathrm{x}$ & $\mathrm{x}$ \\
\hline 10. & Current assets turnover ratio & & $\mathrm{x}$ & & $\mathrm{x}$ & $\mathrm{x}$ & $\mathrm{x}$ \\
\hline 11. & Quick ratio & & & & & $\mathrm{x}$ & $\mathrm{x}$ \\
\hline 12. & Stock turnover ratio & & & & & & \\
\hline 13. & Receivables to liabilities ratio & & & & & $\mathrm{x}$ & $\mathrm{x}$ \\
\hline 14. & Equity profitability index & $\mathrm{x}$ & $\mathrm{x}$ & & & & \\
\hline 15. & Equity debt ratio & $\mathrm{x}$ & $\mathrm{x}$ & & & & \\
\hline 16. & Sale profitability index & $\mathrm{x}$ & $\mathrm{x}$ & & & & \\
\hline 17. & EBITDA/Financial expenses & & $\mathrm{x}$ & & & & \\
\hline
\end{tabular}

Source: own calculations.

The results of both architectures of NN, basing on the sets of data selected for various sectors, are significantly better compared to sets of data when the input was presented by ratios from DA. The results of chosen NN (best results) are presented in Tab. 6.

Tab. 6. Comparison of MLP and RBF neural networks on input ratios selected for sectors

\begin{tabular}{|l|c|c|c|}
\cline { 2 - 4 } \multicolumn{1}{c|}{ Model } & Construction & Quality (\%) & Trade \\
\hline MLP & 96.67 & 91.67 & 95.00 \\
\hline RBF & 95.00 & 91.67 & 93.33 \\
\hline
\end{tabular}

Source: own calculations.

The results of NN quality demonstrate the significance of tailor-made input. The differences between both tested structures are slender - the highest level is $96.67 \%$ for MLP and $91.67 \%$ for RBF. It can be interpreted that the previous differences between individual $\mathrm{NN}$ architectures disappear if the input is selected in advance according to the line of business of the examined entity.

Comparing the results of $\mathrm{NN}$ and DA it can be noticed that $\mathrm{NN}$ do slightly better, though the difference is not very significant. It can be assumed that $\mathrm{NN}$ are more flexible than DA models.

\section{Conclusions}

Credit risk estimation and correct classification of customers is a valid, up-today, significant issue. Therefore, methods are being constantly developed to improve the process of decision-making and new models are being created. The methods cover a wide range of various approaches. Their utility is checked daily in bank practice. The objective of used methods is increased accuracy which means that more creditworthy applicants are granted a loan, thereby increasing bank's profits. 
Consequently, those accounts which are not creditworthy are denied the loan and, thus, avoiding unnecessary losses.

The paper analysed two types of neural networks: Multi-Layer Perceptron and Radial Basis Function. The choice of those types of neural network architecture was dictated by their popularity.

In the research, they both proved to be highly useful in credit risk decision-making process, especially when the input was based on previously selected ratios, according to the line of business of examined entity. The obtained results show that, irrespective of the model and data set, the accuracy is not less than $90 \%$ (among the best ones). It can be concluded that the application of the NN approach to company distress prediction is beneficial for the process of credit risk evaluation.

On the basis of the performed experiments, a conclusion can be drawn that the prior selection of input data (in this case financial ratios) is vital in correct classification of healthy and unsound companies - potential clients of the bank.

In the author's opinion, it is essential in further research to implement various methods of including and excluding the variables - preferably, independently for each method and branch of economy. Moreover, one of the further directions of currently ongoing research, may lead to broadening the set of exogenous factors which, according to the author, significantly influence credit risk.

The alternative direction of research, with respect to this analysis, bases on comparative analysis among neural networks and other approaches to categorising clients (classification trees, regression, etc.) and amid different types of neural networks as well.

\section{Bibliography}

Altman E., Financial Ratios, Discriminant Analysis and the Prediction of Corporate Bankruptcy, "Journal of Finance" 1968, Vol. 23, DOI: https://doi.org/10.1111/j.1540-6261.1968.tb00843.x.

Angelini E., di Tollo G., Roli A., A Neural Network Approach for Credit Risk Evaluation, "The Quarterly Review of Economics and Finance" 2008, Vol. 48,

Appenzeller D., Szarzec K., Prognozowanie zagrożenia upadłościa polskich spótek publicznych, „Rynek Terminowy" 2004, nr 1.

Atiya A.F., Bankruptcy Prediction for Credit Risk Using Neural Networks: A Survey and New Results, "IEEE Transactions on Neural Networks" 2001, Vol. 12(4).

Baesens B., Setiono R., Mues C., Vanthienen J., Using Neural Network Rule Extraction and Decision Tables for Credit-Risk Evaluation, "Management Science" 2003, Vol. 49(3).

Gajdka J., Stos D., Wykorzystanie analizy dyskryminacyjnej w ocenie kondycji finansowej przedsiębiorstw, [in:] R. Borowiecki (red.), Restrukturyzacja w procesie przekształceń i rozwoju przedsiębiorstw, Wydawnictwo AE w Krakowie, Kraków 1996.

Gaudart J., Giusiano B., Huiart L., Comparsion of the Performance of Multi-Layer Perceptron and Linear Regression for Epidemiological Data, "Computional Statistics \& Data Analysis" 2004, Vol. 44.

Hadasik D., Upadtość przedsiębiorstw w Polsce i metody jej prognozowania, Wydawnictwo AE w Poznaniu, Poznań 1998. 
Hamrol M., Czajka B., Piechocki M., Upadtość przedsiębiorstwa - model analizy dyskryminacyjnej, „Przegląd Organizacji” 2004, nr 6.

Haykin S., Neural Networks and Learning Machines, $3^{\text {rd }}$ ed., PHI Learning Private Limited, New Delhi 2011.

Hołda A., Prognozowanie bankructwa jednostki w warunkach gospodarki polskiej z wykorzystaniem funkcji dyskryminacyjnej, „Rachunkowość” 2001, nr 5.

Huang Z., Chen H., Hsu C.J., Chen W.H., Wu S., Credit Rating Analysis with Support Vector Machines and Neural Networks: A Market Comparative Study, "Decision Support Systems" 2004, Vol. 37,

DOI: https://doi.org/10.1016/S0167-9236(03)00086-1.

Karaa A., Krichene A., Credit-risk Assessment Using Support Vectors Machine and Multilayer Neural Network Models: A Comparative Study Case of a Tunisian Bank, "Accounting and Management Information Systems" 2012, Vol. 11(4).

Khemakhem S., Boujelbènea Y., Credit Risk Prediction: A Comparative Study Between Discriminant Analysis And The Neural Network Approach, "Accounting and Management Information Systems" 2015, Vol. 14(1).

Kowalski P.A., An Evolutionary Strategy for Fuzzy Flip-Flop Neural Networks Learning, XIII Krajowa Konferencja „Algorytmy Ewolucyjne i Optymalizacja Globalna”, (KAEiOG 2011), Warszawa, 21-22 września 2011.

Linder R., Geier J., Kölliker M.J., Artificial neural networks, classification trees and regression: Which method for which customer?, "Database Marketing \& Customer Strategy Management" 2004, Vol. 11.

Ogwueleka F.N., Misra S., Colomo-Palacios R., Fernández-Sanz L., Neural Network and Classification Approach in Identifying Customer Behaviour in the Banking Sector: A Case Study of an International Bank, "Human Factors and Ergonomics in Manufacturing \& Service Industries" 2015, Vol. 25(1).

Oreski S., Oreski D., Oreski G., Hybrid system with genetic algorithm and artificial neural networks and its application to retail credit risk assessment, "Expert Systems with Application" 2012, Vol. 39(16).

Nigrin A., Neural Networks for Pattern Recognition, Massachusetts Institute of Technology 1993.

Pacelli V., Azzollini M., An Artificial Neural Network Approach for Credit Risk Management, "Journal of Intelligent Learning Systems and Applications" 2011.

Prusak B., Nowoczesne metody prognozowania zagrożenia finansowego przedsiębiorstw, Difin, Warszawa 2005.

Statistica Help, http://documentation.statsoft.com [access: 10.04.2017].

Stępień P., Strąk T., Wielowymiarowe modele logitowe oceny zagrożenia bankructwem polskich przedsiębiorstw, [in:] D. Zarzecki (red.), Zarzadzanie finansami. Finansowanie przedsiębiorstw w UE, t. 1, Wydział Nauk Ekonomicznych Uniwersytetu Szczecińskiego, Szczecin 2004.

Tollo G., Credit Risk: A Neural Net Approach, 2006, http://tmancini.di.uniroma1.it/rcra/workshops/RCRA2006/files/ditollo.pdf [access: 10.04.2017].

Wędzki D., Wielowymiarowa analiza bankructwa na przykladzie budownictwa, „Badania Operacyjne i Decyzje" 2005, nr 2.

Wierzba D., Wczesne wykrywanie przedsiębiorstw zagrożonych upadłościa na podstawie wskaźników finansowych - teoria i badania empiryczne, „Zeszyty Naukowe Wyższej Szkoły Ekonomiczno-Informacyjnej w Warszawie" 2000, nr 9.

Wójcicka A., Classification of trade sector entities in credibility assessment using neural networks, referat wygłoszony na konferencji „Metody i Zastosowania Badań Operacyjnych”, Czerniejewo, 16-18 października 2016a.

Wójcicka A., Credit-risk decision process using neural networks in industrial sectors, referat wygłoszony na konferencji "International Conference on Accounting, Finance and Financial Institutions. Theory Meets Practice", Poznań, 19-21 października 2016b.

Wójcicka A., Neural networks in credit risk evaluation of construction sector, referat wygłoszony na "Econometric Research in Finance Workshop" w Warszawie, 2016c. 
Pobrane z czasopisma Annales H - Oeconomia http://oeconomia.annales.umcs.pl Data: 26/04/2023 16:58:36

\section{Porównanie wykorzystania sieci neuronowych i analizy dyskryminacyjnej w ocenie niewypłacalności}

W artykule opisano wykorzystanie i użyteczność różnych typów sieci neuronowych i modeli analizy dyskryminacyjnej w procesie określania potencjalnej niewypłacalności dłużnika. Następnie wyniki poszczególnych metod, uzyskane na podstawie danych finansowych przedsiębiorstw pochodzących z różnych sektorów gospodarki, zostały porównane i na tej podstawie określono przydatność badanych metod w procesie oceny ryzyka kredytowego.

\section{Neural Networks vs Discriminant Analysis in the Assessment of Default}

The paper investigates the use of different structure of NN and DA in the process of establishing the possibility of default. The results of those different methods are juxtaposed and their performance is compared. 